\title{
The Effectiveness of YouTube as Learning Media in Improving Learners' Speaking Skills
}

\author{
Putu Enik Kristiani ${ }^{1}$ \\ Universitas Pendidikan Ganesha, Indonesia \\ kristianienik2@gmail.com \\ Diah Ayu Manik Pradnyadewi ${ }^{2}$ \\ Universitas Pendidikan Ganesha, Indonesia \\ diahayumanik06@gmail.com
}

\begin{abstract}
In language learning, speaking becomes the evidence of students' competence of the language that is learnt. However, students' speaking ability can be inhibited by several problems that are faced such as lack of confidence, lack of vocabulary and grammar, and inappropriate teaching strategy. In this era, the developments of information and technology (IT) can be the solution of those problems. The development of technology seems to have many positive effects on education. Technology provides a variety of learning media that is fun for students. One of the technological developments that can be used as learning media is YouTube. YouTube provides various types of videos related to learning. In learning English, EFL learners can find various types of videos that can help the learning process. Therefore, YouTube can help learners to improve their language skill, especially their speaking skills. The aim of this paper is to explain the effectiveness of using YouTube as learning media in improving learner's speaking skills.
\end{abstract}

Keywords: Learning Media; Teaching Speaking Skill; YouTube

\section{INTRODUCTION}

Speaking skill is one of the important language skills in learning English. Speaking can show the competence of the students in learning English (Zyoud, 2016). Moreover, speaking is the common way to communicate with others in order to deliver opinions, questions, and others. However, many students also have several problems in improving their speaking skills. According to Riswandi (2016) the problems that are usually faced by the students in improving their speaking skill are the students feel shy and nervous when they are speaking in front of the class, the students are lack of confidence to answer teacher's question, the students are nervous when they have to present something, the students cannot use the appropriate vocabulary and correct grammar when they are speaking. Further, he also argues that the strategy that is used by many teachers in teaching speaking skill in the classroom is usually monotonous and rarely facilitates students to be an active speaker in the classroom. However, the problems that are faced by the students' speaking skill are able to be improved by providing a new strategy in teaching speaking skill. The strategy can be conducted by taking advantage of technological developments. 
In this era, the developments of technology become an important aspect and can simplify daily life activity. This development certainly provides many benefits and positive impacts for everyone. Technological developments help a lot in the fields of economy, education, health, and others (Chitamba, 2014). In the field of education, technology provides benefits for both learners and teachers. The educational process can be easier to do because there is a lot of information related to learning materials that can be accessed by students through technology. Besides that, technology also provides a fun and easy learning process through a variety of interesting media. According to Raja \& Nagasubramani (2018) information and technology (IT) development can improve learners' interactive learning through the interesting features that are provided in it. Information and technology development provides many sources in learning a language, such as in improving students' speaking skill (Almurashi 2016).

One of the technologies that can be used to improve students' speaking skill is YouTube. Almurashi (2016) states YouTube is an interesting media to use in teaching and learning English. YouTube provides many videos that can be used by the students learning resources. Students can learn English through short English videos, films, and English tutorials. Moreover, Riswandi (2016) in his study found that YouTube can help students to improve their speaking skill, especially in increasing their knowledge about vocabulary, grammar, and pronunciation in English through the videos that are provided in it. Thus, it can be assumed that YouTube can be also an effective learning media for developing students' language skills that can be used by the teachers, especially in developing students' speaking skill.

There were several previous studies that used to support this study. The first one is the study that was conducted by Riswandi (2016) that aimed to describe the impact of YouTube in improving students' speaking skill and the process of teaching and learning speaking skill by using YouTube videos. This study involved 28 students of seventh- grade of one of Junior High School in Surakarta. Qualitative approach was applied in this study. There were two results of the study that were found in this research. First, there was the significant improvement of students speaking skill that was identified in two cycles. On the cycle one of the studies showed that the maximum score of the students' speaking test was 71.7. Meanwhile, the cycle two showed that the maximum score of the students was 80.1. Second, students' perceptions about YouTube that were collected by using questionnaire showed positive responses. All of the students said that they enjoyed the learning activity by using YouTube videos, YouTube was very helpful for them, and YouTube were able to motivate them in learning English because of the new atmosphere in learning, especially in learning and improving their speaking skill. The second previous study was Jati, Saukah, \& Suryati (2019) which analyzed about the teaching using YouTube tutorial video to improve students' speaking skill. The aim of the study was to find out how tutorial video in YouTube can help students to improve their speaking skill performance in performing procedure text. The study involved junior high school in Jombang regency, East Java. The result of the study showed that students' speaking ability was improving when they taught by using the tutorial video from YouTube. Several aspects of students' speaking ability that were improved were accuracy, fluency, and performance. First, the accuracy aspect was improved because tutorial video from YouTube was a source to 
increase their vocabulary and show a good speaking model. Second, fluency aspect was improved because the video provided the pronunciation for the students and also more vocabulary that could be learnt at the same time which made them became more confident in presenting their procedure text. Third, performance aspect was improved because tutorial video from YouTube was a model of how to perform in public. Students were also able to learn about eye contact and body gesture when presenting something. Next, Meinawati, Harmoko, Rahmah, \& Dewi (2020) conducted a study about increasing speaking skill through YouTube. The aim of the study was to investigate the use of YouTube in improving students' speaking skill. The subject of the study were $10^{\text {th }}$ grade students of SMA IT Rahmaniyah. The result of the study showed that YouTube was a good alternative teaching media, especially in teaching language. The score of students' speaking test was improved when they were taught by using YouTube in which the average score of students' speaking test before using YouTube as the learning media was 64 and 77 after using YouTube as the learning media. The researchers also found that students were able to speak expressively and confidently. They were able to imitative the pronunciation that they heard in the video of the native speakers

\section{METHOD}

This study used literature study in collecting the data. The researchers conducted several steps. The first one was collected the data from primary and secondary sources. The primary resources, the data were collected by studying the research papers related to the use of YouTube in learning, particularly in teaching and learning Speaking Skill. In the secondary resources, the researcher collected the data from books and articles which were able to support this study. The second step was analyzing and classifying the collected data, particularly the effectiveness of YouTube as the learning media to improve students' speaking skill. After the data were classified and analyzed, the researcher conducted the last step which was drew the conclusion based on the data.

\section{FINDINGS \& DISCUSSIONS}

YouTube is a web-based service where the users are able to search several videos, comment on the videos, upload a video, and subscribe to the other users (Srinivasacharlu, 2020). There are several videos that are able to be found on YouTube such as movies, music videos, tutorial videos, educational videos, etc. Nasution (2019) states that YouTube is not only providing fun videos to entertain, but also can be used as a learning media to find many educational videos from the beginner level, intermediate level, and advanced level. Further, he states that YouTube facilitates the language learners with many sources that can help them to improve the target language. Sari \& Margana (2019) also states that YouTube is the learning platform that provides the wider space for the students to practice their speaking skill and get more feedback from many people. Jalaluddin (2016, p.2) also states that there are several advantages of YouTube in improving students' speaking skill, as follow:

1. Students can access the video for learning anywhere and anytime. Students can learn and practice to speak English not only in the classroom but also at home by using videos from YouTube. They will have more time to learn than only learning from the teacher in the classroom 
2. Students can get the video of authentic English. Students can learn and improve their speaking skill through the video from the native speakers in YouTube

3. Students can learn in a fun and interesting way. In the classroom, students learn through various videos from YouTube that are provided by the teachers during the learning process which make a different atmosphere than usual. Besides, students can hear the pronunciation, increase that vocabulary, and see the gesture or expression of the speaker in the video. In this context, students also can be motivated to learn and stay in the classroom for a longer time.

4. Students can be more focus to the material and become interactive in learning. Learning by using various and relevant videos from YouTube can help students to focus on what they hear and see during the learning process. The teachers can combine the activity by practicing what they can from the video in the classroom. They will not only hear and see but also speak or produce what they get in the video

5. Students can give comments and suggestions to the video that they watch orally. YouTube not only provides the opportunity to find several videos but also gives an opportunity to upload videos. In this context, the teacher can ask students to make a video and upload it to YouTube and their friend will give comments or questions of the video in the next meeting. This activity will help students to learn how to speak or deliver their opinion about something.

6. Students can find many authentic examples of several expressions in English that are usually used by people in their daily life. YouTube is not only containing of tutorial videos to learn English, but there are also many videos of conversation that can be the learning source, especially in improving speaking skill.

\section{CONCLUSIONS}

Based on the findings and discussions above, YouTube is beneficial learning media in improving students' English language skill, especially speaking skill. YouTube is able to help the students who have introverts' personality to be able to practice and show their speaking ability by uploading their recorded video and get the opportunity to get the feedbacks not only form their teacher and friends but also other people.

\section{REFERENCES}

Almurashi, W. A. (2016). The Effective Use of Youtube Videos for Teaching English. International Journal of English Language and Linguistics Research, 4(3), 32-47.

Chitamba. (2014). Technology and Its Effect in Our Daily Lives. Vaal of Technology, 2(1), 2-9.

Dereh, N. (2019). Bipa Learning Media: Management and Problems. ISLLAC: Journal of Intensive Studies on Language, Literature, Art, and Culture, 3(1), 44-48. https://doi.org/10.17977/um006v3i12019p044

Jalaluddin, M. (2016). Using YouTube to Enhance Speaking Skills in ESL Classroom. English for Specific Purposes World, 17(50), 1-4.

Jati, I. P., Saukah, A., \& Nunung Suryati. (2019). Teaching Using Youtube Tutorial to Improve Students' Speaking Skills. Jurnal Pendidikan Humaniora, 7(3), 101-116. 
Kurniawan, I. (2013). Students' Perception on the Use of YouTube as a Learning Media to Improve Their Speaking Skill. International Journal of Technology in Teaching, 1(2). 324-329

Meinawati, E., Harmoko, D. D., Rahmah, N. A., \& Dewi, N.-. (2020). Increasing English Speaking Skills Using Youtube. Polyglot: Jurnal IImiah, 16(1), 1. https://doi.org/10.19166/pji.v16i1.1954

Musfiqon. (2012). Development of learning media and sources. Jakarta: Prestasi Pustakaraya.

Nasution, A. K. R. (2019). YouTube as a Media in English Language Teaching ( ELT ) Context: Teaching Procedure Text. Journal of Ultimate Reserach and Trends in Education, 1(1), 29-33.

Puspitarini, Y. D., \& Hanif, M. (2019). Using Learning Media to Increase Learning Motivation in Elementary School. Anatolian Journal of Education, 4(2), 5360. https://doi.org/10.29333/aje.2019.426a

Raja, R., \& Nagasubramani, P. C. (2018). Impact of modern technology in education. Journal of Applied and Advanced Research, 3, 33-35. https://doi.org/10.21839/jaar.2018.v3is1.165

Rao, P. S. (2019). The Importance of Speaking Skills in English Classrooms. Alford Council of International English and Lierature Journal (ACIELJ), 2(2), 6-16.

Riswandi, D. (2016). Use of YouTube-Based Videos to Improve Students' Speaking Skill. Proceeding The 2nd International Conference On Teacher Training and Education, 2(1), 298-306. Retrieved from https://jurnal.uns.ac.id/ictte/article/view/8150

Sari, Y. N. \& Margana (2019). YouTube as a Learning Media to Improve the Student's Speaking Ability in $21^{\text {st }}$ Century

Srinivasacharlu, A. (2020). Using Youtube in Colleges of Education. International Journal of Education, 8(2), 21-24. https://doi.org/https://doi.org/10.34293/education.v8i2.1736

Torky, S. A. E. F. (2006). The Effectiveness of a Task- Based Instruction program in Developing the English Language Speaking Skills of Secondary Stage Students A thesis Supervised by. Curricula and Method of Teaching, 2(2), 1-254.

Zyoud, M. M. (2016). Theoretical Perspective on How To Develop Speaking Skill. An International Multidisciplinary Journal, 2(1), 1-10. 